\title{
Phytoremediation Potential of Thistle (Cynara Cardunculus L.) and its Ability to Remove Heavy Metals from Polluted Soils with High Rates of Sewage Sludge
}

\author{
Maria del Mar Delgado ${ }^{1 *}$, Rosario Miralles de Imperial ${ }^{1}$, Isabel González ${ }^{1}$, \\ Carmen Lobo ${ }^{2}$, Antonio Plaza ${ }^{2}$, Sara Martínez ${ }^{3}$, José Valero Martín ${ }^{1}$ \\ ${ }^{1}$ INIA, Environmental Department, Ctra, La Coruña, Km. 7.5, 28040 Madrid, Spain \\ ${ }^{2}$ IMIDRA Agro-Environmental Department, Ctra, Barcelona, Km. 38.2, 28800, Alcalá de Henares Madrid, Spain \\ ${ }^{3}$ Department of Land Morphology and Engineering and Department of Natural Systems and Resources, \\ Universidad Politécnica de Madrid, Ciudad Universitaria s/n 28040 Madrid, Spain
}

Received: 11 November 2016

Accepted: 13 February 2017

\begin{abstract}
This work studied the use of thistle (Cynara cardunculus L) in order to phytoextract heavy metals from polluted soils due to the application of high rates of thermally dried sewage sludge (TDS). Total and available heavy metals content $(\mathrm{Pb}, \mathrm{Cd}, \mathrm{Cu}, \mathrm{Ni}, \mathrm{Zn}$, and $\mathrm{Cr})$ in soil, aerial and root biomass, and extracted heavy metals by both biomasses were analysed. The sewage sludge rate showed a significant difference $(\mathrm{p}<0.05)$ in thistle aerial and root biomass. The highest aerial biomass $(36.87 \mathrm{~g} \mathrm{~d}$.w.) was obtained with the sewage sludge $100 \mathrm{t} \mathrm{ha}^{-1}$ and the lowest with the control (27.84 g d.w.). In relation to root biomass, the highest value was observed in control $(2.65 \mathrm{~g} \mathrm{d.w}$.) and the lowest in the sewage sludge $100 \mathrm{t} \mathrm{ha}^{-1}(0.86 \mathrm{~g}$ d.w.). The content of total and available heavy metals in the soil increased for $\mathrm{Zn}$ and $\mathrm{Cu}$ with increasing sludge doses. The same trend was observed for the available Ni. However, $\mathrm{Pb}$ and $\mathrm{Cd}$ showed a different response as their availability in the soil decreased. The phytoextraction potential of heavy metals by thistle aerial biomass decreased with increasing rates of sewage sludge. Maximum extraction was achieved by using sewage sludge $50 \mathrm{tha}^{-1}$ in $\mathrm{Cd}>\mathrm{Ni}>\mathrm{Pb}>\mathrm{Zn}>\mathrm{Cu}>\mathrm{Cr}$.
\end{abstract}

Keywords: aerial biomass, available heavy metals, root biomass, thermally dried sewage sludge, total heavy metals

\section{Introduction}

The application of sewage sludge as an organic amendment on crops can be one of the main sources of

*e-mail: delgado@inia.es soil contamination by heavy metals. The accumulation of heavy metals can cause adverse effects on soils as well as present a potential risk for the environment [1-2]. Their toxicity depends on the dose applied and other factors, such as the $\mathrm{pH}$ of sewage sludge. Also, it is known that other micro-pollutants present in these wastes can cause 
Table 1. Annexes I A, I B, and I C of Directive 86/278/CEE according to the Spanish legislation ${ }^{1}$ on sewage sludge.

\begin{tabular}{|c|c|c|c|}
\hline & $\begin{array}{c}\text { Limit values for concentrations } \\
\text { of heavy metals in soil } \\
\left(\mathrm{mgkg}^{-1} \mathrm{dw}\right)\end{array}$ & $\begin{array}{c}\text { Limit for heavy metal } \\
\text { concretions in sludge for } \\
\text { use in agriculture } \\
\left(\mathrm{mgkg}^{-1} \mathrm{dw}\right)\end{array}$ & $\begin{array}{c}\text { Limit values for amounts of heavy metal that } \\
\text { may be added annually to agricultural land, } \\
\text { based on a 10-year average } \\
\left(\mathrm{kgha}^{-1} \mathrm{y}^{-1}\right)\end{array}$ \\
\hline Cadmium $(\mathrm{Cd})$ & $1-3$ & $20-40$ & 0.15 \\
\hline Chromium $(\mathrm{Cr})$ & $100-150$ & $1,000-1,500$ & 3 \\
\hline Copper $(\mathrm{Cu})$ & $50-140$ & $1,000-1,750$ & 12 \\
\hline Nickel $(\mathrm{Ni})$ & $30-75$ & $300-400$ & 3 \\
\hline Lead $(\mathrm{Pb})$ & $50-300$ & $750-1,200$ & 15 \\
\hline Zinc $(\mathrm{Zn})$ & $150-300$ & $2,500-4,000$ & 30 \\
\hline
\end{tabular}

${ }^{1}$ BOE, 1990. Royal Decree 1310/1990, October 29

adverse effects on organisms and modify soil properties [3].

According to European and Spanish regulations, sewage sludge qualities are assessed, among other parameters, on the basis of the total concentrations of seven heavy metals (Table 1) [4]. European and Spanish legislation concerning fertilizing products [5] indicate that soil protection should be the main objective when carrying out proper fertilization [6-7].

The practice of amending soils using high doses or continuous applications of sludge has led to contaminated soils. An environmentally friendly and cost-effective alternative is to use contamination techniques. Phytoremediation is a plant-based technology that uses plants with the absorptive capacity of binding heavy metals, such as thistle.

The thistle is a herbaceous species well adapted to the Mediterranean climate, characterised by dry hot summers. It is a very demanding plant regarding nutritive elements, requiring proper fertilisation - both mineral and organic. It also tolerates a certain level of salinity, which in most cases is higher than the

Table 2. Chemical properties of soil and thermally dried sewage sludge (dry matter).

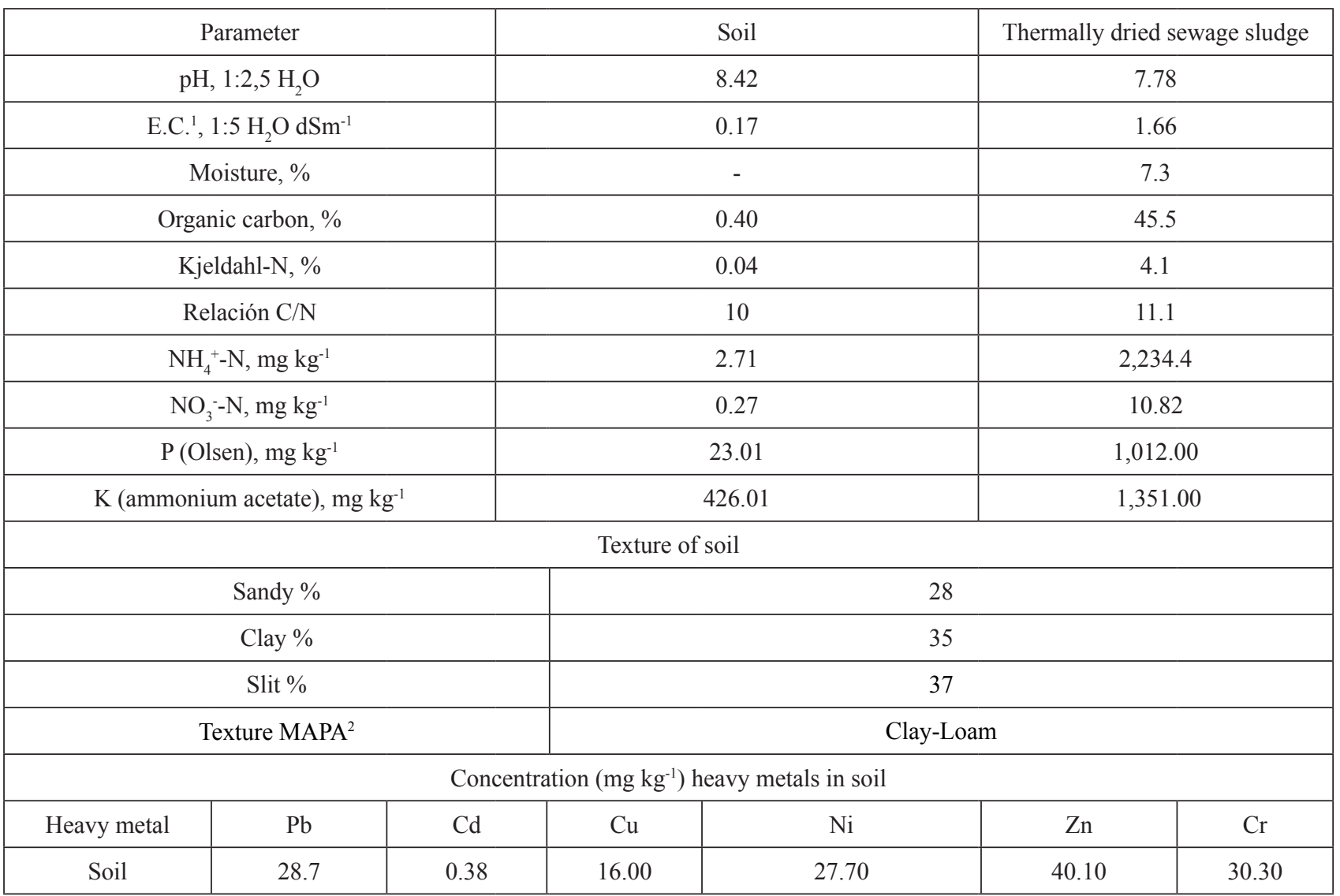

${ }^{1}$ E.C $=$ Electric conductivity, ${ }^{2}$ MAPA $=$ Ministry of Fisheries Agriculture and Food, 1994 
Table 3. Aerial biomass and root biomass of thistle $\left(\mathrm{g}\right.$ plant $\left.{ }^{-1}\right)$ mean at the end of the experiment according to sewage sludge treatment $(\mathrm{SW})$.

\begin{tabular}{|c|c|c|}
\hline Treatment & $\begin{array}{c}\text { Aerial biomass } \\
\left(\mathrm{g} \mathrm{plant}^{-1}\right)\end{array}$ & $\begin{array}{c}\text { Root biomass } \\
\left(\mathrm{g} \mathrm{plant}^{-1}\right)\end{array}$ \\
\hline Control 0 & $27.84 \mathrm{a}$ & $2.65 \mathrm{~b}$ \\
\hline SW 50 & $33.70 \mathrm{ab}$ & $0.89 \mathrm{a}$ \\
\hline SW 100 & $36.87 \mathrm{~b}$ & $0.86 \mathrm{a}$ \\
\hline SW 150 & $35.13 \mathrm{~b}$ & $0.88 \mathrm{a}$ \\
\hline
\end{tabular}

Values in a column with different lowercase letters are significantly different at $\mathrm{p}<0.05$

one tolerated by other species [8]. In recent years, studies have been carried out to investigate the thistle's energetic use due to its high production of lignocellulosic biomass [9] and its capacity to remove heavy metals from contaminated soils by phytoremediation [10-11].

In relation to organic amendments, the organic matter forms metal complexes and chelates with heavy metals. The formation of these compounds can retain the heavy metals, thus modifying their assimilation [12]. In order to facilitate sewage sludge handling in agronomic applications and to be able to apply it using conventional fertilizer spreaders, this sludge will suffer a thermal drying process. As a result of this process a granulated final product will be obtained [13].

The aim of this investigation was to study the phytoremediation capacity of the thistle and the tolerance of this plant to high levels of heavy metals in soils.

\section{Materials and Methods}

A greenhouse experiment with thistle (Cynara cardunculus L.) was carried out between May and October 2013. Soil used (loamy sandy, Haploxeralf calciortidico [14]), was collected from INIA's "La Canaleja" experimental field in Madrid, Spain. Its geographical coordinates are $40^{\circ} 30^{\prime}$ north latitude and $3^{\circ} 17^{\prime}$ west longitude. Thermally dried sewage sludge (TDS) was acquired from a wastewater treatment plant in the Autonomous Community of Madrid.

The experiment was carried out in plastic pots with a capacity of $26 \mathrm{dm}^{3}\left(0.1 \mathrm{~m}^{2}\right.$ of surface and $30 \mathrm{~cm}$ of depth). Four treatments, performed according to a random design (four replicates), were considered: unamended soil $\left(0 \mathrm{tha}^{-1}\right)$, TDS (50 t ha- ${ }^{-1}, 100 \mathrm{tha}^{-1}$, and $\left.150 \mathrm{t} \mathrm{ha}^{-1}\right)$ in dry weight. The total number of pots used in the experiment was 16. During the experiment (May-October 2013), all the pots were watered with spring water and humidity was maintained close to $60 \%$ of the water-holding capacity.

The dose of the sludge treatment was calculated considering that to produce $10 \mathrm{t} \mathrm{ha}^{-1}$ of thistle biomass the nitrogen extraction is about $130 \mathrm{~kg}$ of $\mathrm{N} \mathrm{ha}^{-1}$ (15), considering an average seed density of 10,000 Plants $\mathrm{ha}^{-1}$ and that in each container where a thistle plant was to be grown, nitrogen requirements were $13 \mathrm{~g} \mathrm{pot}^{-1}$. To cover these $\mathrm{N}$ requirements per plant, $333.33 \mathrm{~g}$ dry matter of thermal dried sludge was added to the $26 \mathrm{~kg}$ soil of the container. This dose of sludge, equivalent to $50 \mathrm{t} \mathrm{ha}^{-1}$, would cover the needs of $\mathrm{N}$ of the thistle. For the weight of sludge to be applied, the annual nitrogen mineralization rate was not taken into account (16), considering that this test with thistle and thistle was to be of short duration (six months).

Table 4. Heavy metals concentrations $\left(\mathrm{mg} \mathrm{kg}^{-1}\right)$ in thistle aerial biomass $(\mathrm{AB})$ and root biomass (RB), according to sewage sludge treatment.

\begin{tabular}{|c|c|c|c|c|}
\hline Treatment & Control 0 & SW 50 & SW 100 & SW 150 \\
\hline \multicolumn{5}{|c|}{ Heavy metals concentrations mg kg } \\
\hline $\mathrm{Pb} \mathrm{RB}$ & $3.96 \mathrm{a}$ & $7.53 b$ & $7.21 \mathrm{~b}$ & $7.61 \mathrm{~b}$ \\
\hline $\mathrm{Pb} \mathrm{AB}$ & $1.88 \mathrm{a}$ & $5.79 b$ & $5.90 \mathrm{~b}$ & $7.97 \mathrm{c}$ \\
\hline $\mathrm{Cd} \mathrm{RB}$ & $0.64 \mathrm{a}$ & $1.24 \mathrm{~b}$ & $1.74 \mathrm{c}$ & $1.70 \mathrm{c}$ \\
\hline $\mathrm{Cd} A B$ & $0.45 \mathrm{a}$ & $0.52 b$ & $0.55 b$ & $0.71 \mathrm{c}$ \\
\hline $\mathrm{Cu} \mathrm{RB}$ & $12.91 \mathrm{a}$ & $48.43 b$ & $33.95 \mathrm{c}$ & $37.16 \mathrm{c}$ \\
\hline $\mathrm{Cu} \mathrm{AB}$ & $5.84 \mathrm{a}$ & $7.05 b$ & $7.12 b$ & $8.04 \mathrm{c}$ \\
\hline $\mathrm{Ni} \mathrm{RB}$ & $3.85 \mathrm{a}$ & $9.88 \mathrm{~b}$ & $8.72 \mathrm{c}$ & $10.79 b$ \\
\hline $\mathrm{Ni} A B$ & $1.53 \mathrm{a}$ & $2.30 \mathrm{~b}$ & $3.80 \mathrm{c}$ & $2.77 \mathrm{~b}$ \\
\hline Zn RB & $23.28 \mathrm{a}$ & $124.83 b$ & $119.88 \mathrm{c}$ & $133.52 b$ \\
\hline $\mathrm{Zn} \mathrm{AB}$ & $30.98 \mathrm{a}$ & $49.26 \mathrm{~b}$ & $44.95 \mathrm{~b}$ & $45.55 b$ \\
\hline $\mathrm{Cr} \mathrm{RB}$ & $4.19 \mathrm{a}$ & $6.63 b$ & $5.46 \mathrm{c}$ & $6.25 b$ \\
\hline $\mathrm{Cr} A B$ & $1.80 \mathrm{a}$ & $2.01 \mathrm{~b}$ & $1.90 \mathrm{~b}$ & $1.85 \mathrm{a}$ \\
\hline
\end{tabular}


Table 5. Mean values of total heavy metals (THM) and available heavy metals (AHM) in soil at the end of culture, and extractable heavy metals by thistle plant in aerial biomass (EHMAB) and root biomass (EHMRB) according to sewage sludge treatment.

\begin{tabular}{|c|c|c|c|c|}
\hline & Soil & Soil & Plant & Plant \\
\hline Treatment & $\begin{array}{c}\text { THM } \\
\mathrm{mg} \mathrm{kg}^{-1}\end{array}$ & $\begin{array}{c}\text { AHM } \\
\mathrm{mg} \mathrm{kg}^{-1}\end{array}$ & $\begin{array}{c}\text { EHMAB } \\
\text { mg } \\
\text { planta }^{-1}\end{array}$ & $\begin{array}{c}\text { EHMRB } \\
\text { mg } \\
\text { planta }^{-1}\end{array}$ \\
\hline \multicolumn{5}{|c|}{$\mathrm{Pb}$} \\
\hline Control 0 & $20.25 a$ & $0.2335 c$ & $0.0525 \mathrm{a}$ & $0.0105 b$ \\
\hline SW 50 & $21.75 \mathrm{a}$ & $0.2012 b$ & $0.1951 b$ & $0.0067 \mathrm{a}$ \\
\hline SW 100 & $22.01 \mathrm{a}$ & $0.2012 b$ & $0.2175 b$ & $0.0062 \mathrm{a}$ \\
\hline SW 150 & $22.25 \mathrm{a}$ & $0.1979 \mathrm{ab}$ & $0.2801 \mathrm{c}$ & $0.0067 \mathrm{a}$ \\
\hline \multicolumn{5}{|c|}{$\mathrm{Cd}$} \\
\hline Control 0 & $0.15 a$ & $0.0232 \mathrm{ab}$ & $0.0125 \mathrm{a}$ & 0.0017 \\
\hline SW 50 & $0.14 \mathrm{a}$ & $0.0191 \mathrm{a}$ & $0.0175 \mathrm{ab}$ & 0.0011 \\
\hline SW 100 & $0.14 \mathrm{a}$ & $0.0191 \mathrm{a}$ & $0.0201 \mathrm{ab}$ & 0.0015 \\
\hline SW 150 & $0.16 b$ & $0.0202 \mathrm{a}$ & $0.0251 \mathrm{~b}$ & 0.0015 \\
\hline \multicolumn{5}{|c|}{$\mathrm{Cu}$} \\
\hline Control 0 & $13.20 \mathrm{a}$ & $0.7775 \mathrm{a}$ & $0.1625 a$ & $0.0342 \mathrm{ab}$ \\
\hline SW 50 & $13.25 \mathrm{a}$ & $0.7212 \mathrm{a}$ & $0.2375 b$ & $0.0431 \mathrm{c}$ \\
\hline SW 100 & $14,75 \mathrm{a}$ & $0.9911 b$ & $0.2625 b$ & $0.0292 \mathrm{a}$ \\
\hline SW 150 & $17.51 \mathrm{~b}$ & $1.2525 \mathrm{c}$ & $0.2825 b$ & $0.0327 \mathrm{ab}$ \\
\hline \multicolumn{5}{|c|}{$\mathrm{Ni}$} \\
\hline Control 0 & $21.25 \mathrm{a}$ & $0.1352 \mathrm{a}$ & $0.0425 \mathrm{a}$ & $0.0102 \mathrm{~b}$ \\
\hline SW 50 & $20.51 \mathrm{a}$ & $0.1957 b$ & $0.0775 b$ & $0.0085 \mathrm{ab}$ \\
\hline SW 100 & $21.01 \mathrm{a}$ & $0.2805 \mathrm{~d}$ & $0.1401 \mathrm{c}$ & $0.0075 \mathrm{ab}$ \\
\hline SW 150 & $21.28 \mathrm{a}$ & $0.3325 \mathrm{e}$ & $0.0975 b$ & $0.0095 b$ \\
\hline \multicolumn{5}{|c|}{$\mathrm{Zn}$} \\
\hline Control 0 & $37.78 \mathrm{a}$ & $1.3097 \mathrm{a}$ & $0.8625 \mathrm{a}$ & $0.0617 \mathrm{a}$ \\
\hline SW 50 & $50.55 b$ & $1.4401 \mathrm{a}$ & $1.6601 \mathrm{~b}$ & $0.1111 b$ \\
\hline SW 100 & $65.76 \mathrm{c}$ & $2.1575 b$ & $1.6575 b$ & $0.1031 b$ \\
\hline SW 150 & $71.14 \mathrm{c}$ & $3.8475 \mathrm{c}$ & $1.6001 \mathrm{~b}$ & $0.1175 b$ \\
\hline \multicolumn{5}{|c|}{$\mathrm{Cr}$} \\
\hline Control 0 & $26.25 \mathrm{a}$ & $2.5375 b$ & $0.0501 \mathrm{a}$ & $0.0111 b$ \\
\hline SW 50 & $26.31 \mathrm{a}$ & $1.3625 \mathrm{a}$ & $0.0675 b$ & $0.0057 \mathrm{a}$ \\
\hline SW 100 & $26.51 \mathrm{a}$ & $1.6751 \mathrm{a}$ & $0.0701 b c$ & $0.0047 \mathrm{a}$ \\
\hline SW 150 & $27.75 \mathrm{a}$ & $2.7625 b$ & $0.0651 b$ & $0.0055 \mathrm{a}$ \\
\hline
\end{tabular}

Values in a column with different lowercase letters are significantly different at $\mathrm{p}<0.05$

The TDS application rates were calculated by taking into account the $\mathrm{N}$ requirement to obtain the greatest thistle yield [15-16]. TDS dose equivalent of $50 \mathrm{t} \mathrm{ha}^{-1} \mathrm{~N}$ covered the thistle's needs. However, as the objective of
Table 6. Heavy metals applied by pot (HMA) according to sewage sludge treatment and extracted heavy metals (EHM) at the end of the thistle culture by aerial biomass and efficiency phytoextraction $(\mathrm{EPHM}=(\mathrm{EHM} / \mathrm{HMA}) \times 100))(\%)$.

\begin{tabular}{|c|c|c|c|}
\hline Treatment & SW 50 & SW 100 & SW 150 \\
\hline \multicolumn{4}{|c|}{$\mathrm{Pb}$} \\
\hline $\operatorname{HMA}\left(\mathrm{mg} \operatorname{pot}^{-1}\right)$ & 43.33 & 86.67 & 130.00 \\
\hline EHM (mg plant ${ }^{-1}$ ) & 0.1951 & 0.2175 & 0.2801 \\
\hline EPHM (\%) & 0.45 & 0.25 & 0.22 \\
\hline \multicolumn{4}{|c|}{$\mathrm{Cd}$} \\
\hline $\operatorname{HMA}\left(\mathrm{mg} \operatorname{pot}^{-1}\right)$ & 0.35 & 0.70 & 1.05 \\
\hline EHM (mg plant ${ }^{-1}$ ) & 0.0175 & 0.0201 & 0.0251 \\
\hline EPHM (\%) & 5.00 & 2.86 & 2.39 \\
\hline \multicolumn{4}{|c|}{$\mathrm{Cu}$} \\
\hline HMA (mg pot $\left.{ }^{-1}\right)$ & 86.67 & 173.33 & 260.00 \\
\hline EHM (mg plant ${ }^{-1}$ ) & 0.2375 & 0.2625 & 0.2825 \\
\hline ЕРHM (\%) & 0.27 & 0.15 & 0.11 \\
\hline \multicolumn{4}{|c|}{$\mathrm{Ni}$} \\
\hline HMA (mg pot $\left.{ }^{-1}\right)$ & 15.67 & 31.33 & 47.00 \\
\hline EHM (mg plant ${ }^{-1}$ ) & 0.0775 & 0.1401 & 0.0975 \\
\hline ЕРНM (\%) & 0.49 & 0.45 & 0.21 \\
\hline \multicolumn{4}{|c|}{$\mathrm{Zn}$} \\
\hline HMA (mg pot $\left.{ }^{-1}\right)$ & 440.66 & 881.32 & 1321.99 \\
\hline EHM (mg plant ${ }^{-1}$ ) & 1.6601 & 1.6575 & 1.6001 \\
\hline ЕРНM (\%) & 0.37 & 0.19 & 0.12 \\
\hline \multicolumn{4}{|c|}{$\mathrm{Cr}$} \\
\hline HMA (mg pot $\left.{ }^{-1}\right)$ & 46.67 & 93.33 & 140.00 \\
\hline EHM (mg plant ${ }^{-1}$ ) & 0.0675 & 0.0701 & 0.0651 \\
\hline ЕРНM (\%) & 0.14 & 0.07 & 0.05 \\
\hline
\end{tabular}

this test was to evaluate the phytoremediation power of thistle in soils contaminated by heavy metals from the application of TDS, very high doses such as $100 \mathrm{tha}^{-1}$ and $150 \mathrm{t} \mathrm{ha}^{-1}$ were applied.

TDS was applied before sowing and chemical properties of soil and TDS were determined according to standard methods (Table 2) [17].

The final harvest was completed in October 2013, when plants reached physiological maturity, showing a straw color (six month after planting). Plants were then subdivided into root biomass and aerial biomass to calculate the efficiency of heavy metals phytoextraction.

The concentration of metals was determined according to USEPA [18]. We used plasma emission spectrometry to analyze heavy metals such as $\mathrm{Cd}, \mathrm{Cr}, \mathrm{Pb}$, and $\mathrm{Ni}$ (Varian Liberty AX, Victoria, Australia), whereas we used atomic absorption spectroscopy to analyze $\mathrm{Zn}$ and $\mathrm{Cu}$ 
(Varian AA 240 FS). The extractable metal content (bioavailable) in soil samples was analyzed according to the procedure described by Lindsay and Norvell using DTPA (diethylamine-pentaacetic acid) [19].

To analyze heavy metals in plants, the plants were rinsed with high-purity MQ water to remove soil particles and oven-dried $\left(70^{\circ} \mathrm{C}\right)$ to a constant weight to determine dry biomass. Aerial biomass and root biomass were weighed separately and the biomass was expressed in $g$ plant $^{-1}$. Then plant material was ground and calcined in the oven at $480^{\circ} \mathrm{C}$. The ashes were digested with HCL (37\%) according to Garate, Ramon, and Caperna [20]. The concentration of metals in plant extracts was analyzed by plasma emission spectrometry (Varian Liberty AX, Victoria, Australia).

Extractable heavy metals by thistle plant in aerial biomass (EHMAB) and root biomass (EHMRB) have been proposed as indicative parameters of studying the mobility of metals from the soil to the plant (Table 5) [21]. To quantify the thistle's phytoremediation and the phytoextraction efficiency of these metals $(\mathrm{EPHM}=(\mathrm{EHM} / \mathrm{HMA}) \times 100)$ was potentially calculated (Table 6) [10].

To determine the effect of the sludge doses, a variance analysis (ANOVA) with the dose as the factor was performed. When the ANOVA was significant $(\mathrm{p}<0.05)$, Duncan's multiple range test was then carried out. This test consists of a multiple comparison of averages, and in order to perform this test we used Statgraphics XVI (Centurion).

\section{Results and Discussion}

Table 2 showed the results of the chemical properties of thermally dried sewage sludge that could be recycled through application to agricultural land as a source of plant nutrients $(\mathrm{N}, \mathrm{P}$, and $\mathrm{K}$ ) and organic matter, as well as a soil amendment (carbon organic) to enhance the future crop production by improving soil quality. However, it will be necessary to study their heavy metals concretions to use in agriculture (Table 1).

The values obtained for the thistle's aerial part and root biomass at the end of the experiment in relation to the TDS treatment and doses are given in Table 3. These results indicate that the addition of TDS had a positively significant effect $(p<0.05)$ on the aerial part of the biomass. However, the effect on the root biomass was found to be negatively significant for all the TDS doses compared to the control, which in this case reached a significant value of $\mathrm{p}<0.05$.

The highest weight of the aerial part biomass was achieved using sewage sludge (dose 100) with a value of $36.7 \mathrm{~g}$ and the lowest was observed in the control (dose 0 ), which weighed $27.84 \mathrm{~g}$. Delgado et al. carried out field experiments with cereal crop fertilizer applying TDS and mineral fertilizers. Results showed that the content of dry matter increased along with the application of increasing sludge doses [22].
On the other hand, the highest weight of root biomass in this study was achieved by the control and was $2.65 \mathrm{~g}$ compared to the $0.89 \mathrm{~g}$ of sewage sludge 50 . Similar results were observed in the experiments conducted by Miralles de Imperial et al. [23] with sorghum crop fertilized using poultry manure. These authors noticed a higher root development in control plants, which was associated with the lack of nutrients and, therefore, a need for the roots to explore the entire pot to absorb them. The root system of the thistle plant tends to be very deep when grown in field conditions and is identified to be a perfectly adapted species in order to obtain abundant biomass production [24-25].

Table 4 shows the heavy metal concentration in thistle aerial biomass $(\mathrm{AB})$ and root biomass (RB) expressed both in $\mathrm{mg} \mathrm{kg}^{-1}$. It is interesting to note that the values of the concentrations of the six heavy metals studied were higher in the thistle's root biomass than the ones obtained for the aerial part.

The average values of total and available heavy metals (THM and AHM) in soil after harvesting and which were extracted by the thistle's aerial part (HMEAB) and root biomass (HMERB) for the different sewage sludge treatments are described in Table 5. In contrast to the previous results, the MPEBA and MPEBR values, calculated by multiplying the concentrations by their aerial part biomass and root biomass weights, respectively, were greater for the aerial part than for the root biomass. Only $\mathrm{Cu}$ and $\mathrm{Zn}$ were significant for THM, while for AHM the six studied metals were significant. The results listed in Table 5 regarding the THM concentrations in soils treated with sludge after the thistle crop indicate lower values for the six heavy metals studied than the reference values adopted for contaminated soils in the autonomous community of Madrid, which are described in BOCM [26].

In this investigation, where thistle was fertilized using thermally dried sewage sludge, the results for the available heavy metals (AHM) in soil after harvesting showed that the availability of $\mathrm{Pb}$ and $\mathrm{Cd}$ was lower when applying the three doses $(50,100$, and 150) of sewage sludge than when no sewage sludge was applied (control with dose 0).

The application of sewage sludge led to a higher retention of these two toxic metals and therefore it positively influenced their availability toward the plant. The same effect of reducing the availability of $\mathrm{Pb}$ in soils when an organic amendment is used was also observed by Walter et al. [27]. The current investigation stated that the availability of heavy metals not only was influenced by the organic matter content, but also due to the concentration of heavy metals. Not all the heavy metals reacted in the same way. In the sludge treatment, the availability of $\mathrm{Cu}, \mathrm{Ni}$, $\mathrm{Zn}$, and $\mathrm{Cr}$ increased along with higher doses. However, no increase was found for $\mathrm{Pb}$ or $\mathrm{Cd}$ (Table 5). Walter et al. [28] performed a long-term field experiment over six years with the aim of studying total and available heavy metals $(\mathrm{Zn}, \mathrm{Pb}, \mathrm{Cd}, \mathrm{Ni}, \mathrm{Cr}$, and $\mathrm{Cu})$ content in soils after a wheat crop. The sewage sludge came from two wastewater treatment plants of Madrid and the doses applied where 
50 and $100 \mathrm{tha}^{-1}$. It was found that the concentrations of THM and AHM (extracted with DTPA) during the crop's first years, increased for $\mathrm{Zn}, \mathrm{Cu}, \mathrm{Pb}$, and $\mathrm{Ni}$. In contrast, during the last years of the experiment, the concentrations decreased. These authors considered that the content of organic matter of these sewage sludges affected the availability of heavy metals.

In this experiment's soil treated with sludge as fertilizer, the extracted $\mathrm{Cd}$ carried out by the aerial part of the biomass was significantly higher compared to the control. Whereas, extracted $\mathrm{Cd}$ by the root biomass was not significant for any of the sludge treatment doses. Llugany et al. [11] performed tests studying a hydroponic crop of Cynara cardunculus and its response to different $\mathrm{Cd}$ solutions. The authors observed that this species presented a certain tolerance to $\mathrm{Cd}$ because its biomass production was not affected by the metal concentration. It was concluded that this plant was suitable for phytoremediation of Cd-contaminated soils. Following a similar tendency, in the current study, the thistle was also capable of extracting $\mathrm{Cd}$ from the soil, being the production of the aerial parts lower in the case of the control and no adverse effects in this production was observed when treating the soil with different sludge doses.

Table 4 contains the results of the HMERB by the thistle and it can be noticed that the higher extractions by the roots were for $\mathrm{Zn}$ and $\mathrm{Cu}$. When comparing the concentrations of the total heavy metals in soil at the end of thistle culture (Table 5) with a previous investigation [29], it could be noted that the same heavy metal, $\mathrm{Zn}$, presented the highest concentration in the soil due to the sludge application.

Regarding the concentration of heavy metals in the thistle's aerial parts, the concentration of $\mathrm{Cd}$ in the biomass was found to be higher for the control and for the sewage sludge doses $(50,100$, and 150$)$ compared to its concentration in soil (Table 4). The fact that the thistle's biomass is capable of retaining this metal demonstrates the effectiveness of employing this species for the phytoremediation of Cd-contaminated soils.

The concentrations of $\mathrm{Zn}$ and $\mathrm{Cu}$ obtained in the aerial parts were higher for the sludge-amended tests with doses of 50,100, and 150 compared to the control, which had no organic fertilization. These results were associated with the fact that the thistle requires $\mathrm{Zn}$ and $\mathrm{Cu}$ for its appropriate development, as it is a very demanding plant in relation to micro-and macronutrients [15].

The phytoextraction efficiency of six metals by the aerial parts is listed in Table 6 . The highest phytoextraction efficiency was achieved for the $\mathrm{Cd}$, with a value of $5 \%$ for a sewage sludge dose of 50 (L 50), 2.87\% for a dose of 100 (L 100), and 2.39\% for 150 (L 150). The Cd phytoextraction efficiency gradually decreased as the sludge doses increased. The phytoextraction efficiency for the other five metals $(\mathrm{Ni}, \mathrm{Pb}, \mathrm{Zn}, \mathrm{Cu}$, and $\mathrm{Cr}$ ) was lower than for $\mathrm{Cd}$ and decreased as the sludge doses increased. The highest efficiency was achieved for $\mathrm{Cd}$ when applying a sludge dose of 50, and for higher doses - such as 100 and 150 - the Cd efficiency was lower.
These results were similar to the ones reported by Hernández-Allica et al. [10]. In their study, three crops (wheat, rapeseed, and thistle) were analyzed under hydroponic conditions, calculating the phytoextraction efficiency percentage of two metals: $\mathrm{Zn}$ and $\mathrm{Cd}$. They concluded that the application of large amounts of heavy metals with sewage sludge does not increase calculated phytoextraction efficiency (\%), but total extracted heavy metals concentration increases.

Mosquera-Losada [16] performed an investigation in Spain studying the agronomical characterization of three sewage sludge types (composted, anaerobically digested, and pelletized) from several wastewater treatment plants. The authors stated that some sewage sludges contained high concentrations of $\mathrm{Cd}, \mathrm{Pb}$, and $\mathrm{Zn}$, and suggested that their concentrations needed to be reduced in order to use it as organic fertilizer.

In the present study using thistle and sludge amendments, a similar tendency of $\mathrm{Zn}$ and $\mathrm{Cd}$ accumulation in soil was observed with the addition of high sludge doses.

\section{Conclusions}

The content of total and available heavy metals in the soil increased for $\mathrm{Zn}$ and $\mathrm{Cu}$ with increasing sludge doses. The same trend was observed for available Ni. However, $\mathrm{Pb}$ and $\mathrm{Cd}$ showed a different response, as their availability in the soil decreased. In the aerial biomass the concentration of heavy metals was higher than in the root biomass. These results show the potential of the thistle to be used as a phytoremediate species to extract cadmium in soils contaminated by heavy metals from high doses of sewage sludge.

The extraction efficiency of this plant regarding heavy metals provided by the sludge $(\mathrm{Ni}, \mathrm{Pb}, \mathrm{Zn}, \mathrm{Cu}$, and $\mathrm{Cr}$ ) resulted in a low value. In this study, the thistle behaved as a decontamination plant even at high doses, removing the heavy metals, in particular $\mathrm{Cd}$, which is bound to the organic matter of the sludge with a dose of $50 \mathrm{tha}^{-1}$. In the present investigation, the findings showed that there was an inverse proportionality between the sludge dose and the extraction efficiency of the heavy metals.

The sludge amendments resulted in a positive effect on the biomass production of the thistle compared to the control due to the nutrients provided. No phytotoxic effects were observed with the three sludge doses. However, the development of the root biomass decreased in comparison to the control, which led to a negative impact on the thistle's capacity to extract heavy metals from soils.

The extrapolation of these results to field tests would require a repeat of this investigation in experimental plots and to increase the density of plants per hectare. By performing these experiments in plots, the phytoextraction efficiency of heavy metals will experience an increase due to the higher number of thistle plants. 


\section{Acknowledgements}

Support for this work has been provided by Spanish Projects FP09-08-CC. The authors wish to thank Ángela García and Jesús García for their technical assistance.

\section{References}

1. LAKHDAR A., IANNELLI M.A., DEBEZ A., MASSACCI A., JEDIDI N., ABDELLY C. Effect of municipal solid waste compost and sewage sludge use on wheat (Triticum aestivum): growth, heavy metal accumulation and antioxidant activity. J. Sci. Food Agric. 90, 965, 2010.

2. BARRAL M., PARADELO R., MOLDES A.B., DAURGUER M.M., FREIRE. F.D. Utilization of MSW compost for organic matter conservation in agricultural soil of NW Spain. Resour. Conserv. Recy. 53, 529, 2009.

3. HOWARD P.H., MUIR D.C. Identifling new persistente and bioaccumulative organics among chemicals in commerce. Environ. Sci. Technol. 44, 2277, 2010.

4. BOE. Real Decreto 1310/1990, (Directive 86/278/CEE) de 29 octubre, por el que se regula la utilización de los lodos de depuración en el sector agrario. Boletín Oficial del Estado 262, 32339, 1990.

5. BOE. Real Decreto 506/2013, (Regulations (EC) No $1069 / 2009$ and (EC) No 1107/2009 of the European Parliament and of the Council) de 28 de junio, sobre productos fertilizantes. Boletín Oficial del Estado 164, $51119,2013$.

6. GONZÁlEZ J., PÉREZ F., FERNÁNDEZ J., LEZAUN J.A., RODRÍGUEZ D., PEREA F., ROMERO C., OCHOA M.J., GRACIA M. Study of Cynara cardunculus L. lignocelullosic biomass production in dry conditions. Acta Horticulturae. 660, 221, 2004.

7. TSADILA, E., TSADILAS C., STAMATIADIS S., CHRISTODOULAKIS N. Investigation of soil property changes and olive tree stress as caused by excessive sewage sludge application. Communications in Soil Science and Plant Analysis. 40, 514, 2009.

8. LAG-BROTONSA.J., SORIANO J.M., GÓMEZNAVARRO J. Saline irrigation effects on Cynara cardunculus L. plants grown in Mediterranean soils. Hortscience. 48, 762, 2013.

9. MANTINEO M., D’AGOSTA G.M., COPANI V., PATANÈ C., COSENTINO S.L. Biomass yield and energy balance of three perennial crops for energy use in the semi-arid Mediterranean environment. Field Crops Research. 114, 204-213, 2009.

10. HERNÁNDEZ-ALLICA J., GARBISU C., BARRUTIA O., BECERRIL J.M. EDTA-induced heavy metal accumulation and phytotoxicity in cardoon plants. Environmental and Experimental Botany. 60, 26. 2007.

11. LLUGANY M., MIRALLES R., CORRALES I., BARCELÓ J., POSCHENRIEDER. C. Cynara cardunculus a potentially useful plant for remediation of soils polluted with cadmium or arsenic. Journal of Geochemical Exploration. 123, 122, 2012.

12. RODRÍGUEZ J.A., LÓPEZ M., GRAU J. Heavy metals, organic matter and other parameters of agricultural soils and pastures of Spain. Edita Ministerio de Medio Ambiente y Medio Rural y Marino. Madrid. 225 pp. 2009.

13. DELGADO M., MIRALLES DE IMPERIAL R., RODRÍGUEZ M.C., MARTÍN J.V. Influence of fertilization with thermally dried sludge in soil chemical properties of three cereal crops. ITEA. 109, 1, 2013.

14. SOIL SURVEY STAFF, NRCS. Keys to soil taxonomy. 11 th ed. USDA- Natural Resources Conservation Service. Washington. 374, 2010.

15. FERNÁNDEZ J. The cultivation of thistle (Cynara cardunculus L.) for biomass production. Hojas divulgadoras, núm. 2130 HD. Ministerio de Medio Ambiente y Medio Rural y Marino. Madrid. 43, 2009.

16. MOSQUERA-LOSADA, M.R., MUÑOZ-FERREIRO N., RIGUEIRO-RODRÍGUEZ A. Agronomic characterization of different types of sewage sludge: Policy implications. Waste Management. 30, 492, 2010.

17. APHAAWWA WPCF. Standard Methods for the Examination of water and Wastewater. $21^{\text {st }}$ ed. American Public Health Association, American Water Works Assotiation and Water Environment Federation, Washington, 874, 2005.

18. USEPA. Method 3051A Microwave assisted acid digestion of sediments, sludges, soils, and oils. US Governement Print Office. Washington. 2007.

19. LINDSAY W.L., NORVELL W.A. Development of a DTPA soil test for zinc, iron, manganese and copper. Soil Science Society American Journal. 42, 421, 1978.

20. GARATE A., RAMÓN A.M., CARPENA O.R. Influence of boron on manganese and other nutrients in extracts of vascular tissues. Anales de Edafología y Agrobiología. 3, 14567, 1984.

21. SINGH R.P., AGRAWAL M. Effects of sewage sludges amendment on heavy metal accumulation and consequente responses of Beta Vulgaris plants. Chemosphere. 67, 2229, 2007.

22. DELGADO M., MARTÍN J.V., MIRALLES DE IMPERIAL R. Evaluation of a thermally dried sludge in the fertilization of cereal cultivation. ITEA. 106, 53, 2012.

23. MIRALLES DE IMPERIAL R., MARTÍN J.V., CALVO R., DELGADO M. The application of poultry manure in forage sorghum as an energy crop. Revista Internacional de contaminación Ambiental. 27, 3, 2011.

24. FERNÁNDEZ J., CURT M.D, AGUADO P.L. Industrial application of Cynara cardunculus L. for energy and other uses. Industrial. Crops Production. 24, 222, 2006.

25. BELL F.P., JAMES C., CHANEY R.L. Heavy metal extractability in long term sewage sludge and metal salt amended soils. J. Environ. Qual. 20, 481, 1991.

26. BOCM. Orden 2770/2006, de 11 de agosto, de la Conserjería de Medio Ambiente y Ordenación del Territorio. Levels generics of heavy metals and other elements traces in contaminated soils of Madrid community. Boletín Oficial de La Comunidad de Madrid. 204, 29, 2006.

27. WALTER I., MARTÍNEZ L., CUEVAS G. Extractable soil heavy metals following the cessation of biosolids application to agricultural soil. Environmental Pollution. 117, 315, 2003.

28. WALTER I., MIRALLES DE IMPERIAL R., FUNES E., GOROSPE M.J., BIGERIEGO M. Effect of sewage sludge as fertilizer in the central region of Spain. En: Treatment and use of sewage sludge and liquid agricultural wastes. Edited by P.L'Hermite. Elsevier Applied Science. London and New York. 304, 1991.

29. BALDANTONI D., LEONE A., IOVIENO P., MORRA L., ZACCARDELLI M., ALFANI. Total and available soil trace element concentrations in two Mediterranean agricultural systems treated with municipal waste compost or conventional mineral fertilizers. Chemosphere. 80, 1006, 2010. 